\title{
Ergot Alkaloids and their Hallucinogenic Potential in Morning Glories
}

Authors

Ulrike Steiner ${ }^{1}$, Eckhard Leistner ${ }^{2}$

Affiliations

1 Institut für Nutzpflanzenwissenschaften und Ressourcenschutz (INRES), Rheinische Friedrich-Wilhelms-Universität Bonn, Germany

2 Institut für Pharmazeutische Biologie, Rheinische Friedrich-Wilhelms-Universität Bonn, Bonn, Germany

Key words

Ipomoea asarifolia, Turbina corymbosa, Convolvulaceae, Clavicipitaceae, Periglandula, ergot alkaloids, hallucinogens

received December 6, 2017

revised January 24,2018

accepted February 5, 2018

Bibliography

DOI https://doi.org/10.1055/a-0577-8049

Published online March 2, 2018 | Planta Med 2018; 84: 751758 @ Georg Thieme Verlag KG Stuttgart · New York | ISSN 0032-0943

Correspondence

Prof. em. Dr. Eckhard Leistner

Institut für Pharmazeutische Biologie, Universität Bonn

Nußallee 6, 53113 Bonn, Germany

Phone: + 49222515049

eleistner@uni-bonn.de

\section{ABSTRACT}

Naturally occurring and semisynthetic ergot alkaloids play a role in health care or as recreational drugs in Western and indigenous Mexican societies. Evidence is summarized that ergot alkaloids present in Central American Convolvulaceae like Turbina corymbosa, Ipomoea violacea, and Ipomoea asarifolia are colonized by different species of a newly described clavicipitaceous fungal genus named Periglandula. The fungi are associated with peltate glandular trichomes on the adaxial leaf surface of its host plants. The Periglandula fungi are not yet culturable in vitro but were demonstrated to have the capacity to synthesize ergot alkaloids. The alkaloids do not remain in the fungal mycelium but are translocated via the glandular trichomes into their plant host. Both fungi and host benefit from a symbiotic lifestyle. In evolutionary terms the alkaloid biosynthetic gene cluster in the Periglandula/Ipomoea symbiosis is likely to have a conserved (basic) structure while biosynthetic ergot gene clusters within the genera Claviceps and Epichloe were under ecological selection for alkaloid diversification.

\section{Introduction}

Ergot alkaloids belong to an outstanding group of natural products that has been extensively studied for its chemical, biological, and medical aspects. Spores (ascospores or conidia) of different fungal species belonging to the family Clavicipitaceae infect ovaries of cultured or noncultured grasses and form sclerotia containing ergot alkaloids. Sclerotia formed on rye plants (Secale cereale L.) are called Secale cornutum with reference to its hornlike shape [1]. The isolation and identification of ergot alkaloids testifies to the experimental skills and ingenuity of natural product chemists, prominent among them Arthur Stoll and Albert Hofmann [2]. Ergot alkaloids are 3,4-substituted indole derivatives with an essential structural element, the tetracyclic ergoline ring system that is variously substituted at C-8 [3]. The nomenclature of the ergoline scaffold, its substitution pattern, and structural variation has been described [3-6].

Ergot alkaloids represent a class of natural products that is notorious for its many physiological activities that may be either beneficial in health care or detrimental in abuse or when mankind and animals are exposed to their toxicity [7]. The nootropic or psychotropic effect of ergot alkaloids are often referred to as hallucinogenic, which holds true for lysergic acid diethylamide (LSD) [8]. It has been pointed out, however, that ergot alkaloids (such as lysergic acid amides, $>$ Fig. 1) may have a pronounced narcotic component [8-10] or result in a hypnotic state in the case of ergot alkaloids present in seeds of Argyreia nervosa [10].

The present review gives an account of the role ergot alkaloids play in Western and indigenous Mexican societies. Moreover, an explanation is presented for the occurrence of ergot alkaloids in higher dicotyledonous plants such as Morning Glories (e.g., Ipomoea asarifolia and Turbina corymbosa). During evolution these plants or a predecessor plant recruited a clavicipitaceous fungus forming a symbiosis. The alkaloids produced by the fungus are beneficial to the symbiotic system in its particular ecological setting. The gene cluster encoding the enzymes of the ergot alkaloid pathway have been sequenced. When compared with clusters of other clavicipitaceous alkaloid-producing fungi, the fungus sym- 
<smiles>CCN(CC)C(=O)C1C=C2c3cccc4[nH]cc(c34)C[C@H]2N(C)C1</smiles>

Lysergic acid diethylamide LSD<smiles>CN1CC(C(N)=O)C=C2c3cccc4[nH]cc(c34)C[C@]21C</smiles>

Lysergic acid amide Ergine

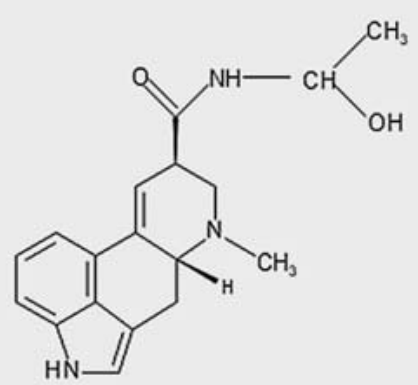

Lysergic acid alpha-hydroxyethylamide

- Fig. 1 A semisynthetic hallucinogen (LSD) and two naturally occurring hallucinogens with a narcotic component (lysergic acid amide and lysergic acid $\alpha$-hydroxyethyl amide). Isoforms of the alkaloids are not depicted.

biotic with I. asarifolia represents a conserved (basic) sequence that came to a relatively early evolutionary halt. Nevertheless, ergot alkaloids in general are the result of an ecological optimization process forming physiologically active compounds that are not only active against a predator but are also likely to stabilize the physiology of the whole symbiotic system. The alkaloids also exert an effect on mankind and livestock. The ergot alkaloids are a convincing example that demonstrates how ecologically optimized natural products were successfully developed into medications.

\section{Ergot Alkaloids in Disease and Health Care}

The principal route of human exposure to ergot alkaloids is by consumption of contaminated food or inhalation of grain dust [11]. Flour contaminated with S. cornutum caused severe disabilities and death in former millennia in Europe, but more recently, mass poisonings were also reported from India [11]. The symptoms and appearances of disabled people suffering from ergotism have plagued mankind for centuries and have been impressively illustrated by painters [12].

It is likely that in the 17th century in New England, people apparently suffering from ergotism were convicted as bewitched because of their strange appearance and behavior. In spite of a good reputation, some were accused of witchcraft, put on trial, and sent to the gallows [13].

Since analytical techniques are becoming more and more sensitive, ergot alkaloids are often detectable in rye flours, bread, and other grain foods, sometimes at levels exceeding $1000 \mu \mathrm{g} / \mathrm{kg}$. The alkaloids partly survive baking and brewing. Breastfed babies whose mothers were given ergot extracts after delivery showed signs of ergotism [11]. This observation, however, is at variance with a report on an ergot epidemic in which whole families were affected, but breastfed infants tended to be spared [14]. Given the varying effects of ergot alkaloids and their profiles in different Claviceps strains (vide infra), both statements $[11,14]$ are probably correct and should not be considered controversial.

Ergot alkaloids are biosynthesized by Claviceps purpurea and by other clavicipitaceous fungi such as seed transmissible Epichloe species causing infestations on forage grasses among them tall fescue (Lolium arundinaceum [Schreb.] Darbysch), sleepygrass (Achnatherum robustum [Vasey] Barkworth), or drunken horse grass (Achnatherum inebrians [Hance] Keng ex Tzvelev). There is a growing concern among farmers and veterinarians about the health and fertility of livestock that is compromised by feeding on infected grasses [11, 15-18].

Different strains of $C$. purpurea may give rise to $S$. cornutum containing variable alkaloid profiles. This and the changing permeability of the blood brain barrier for the ingested alkaloids and the receptor heterogeneity of G-protein coupled membrane proteins may result in different symptoms, among these gangrenous or convulsive ergotism $[11,14]$. The gangrenous condition leads to an ischemia mainly in limbs, loss of sensation, change in color, and falling away of the affected body parts with a high incidence of mortality while the convulsive ergotism causes painful distortion of trunk, limbs, fingers, and abnormal postures. People appear drowsy, lethargic, and suffer from double vision and hallucinations. Due to the habitat preferences of different Claviceps strains [19], convulsive ergotism prevailed east and north, however, gangrenous west of the river Rhine [14].

In the 17th century Francisco Hernándes, physician to Philipp II, King of Spain, described the T. corymbosa plant and its use by the native Indian population in the book "Rerum Medicarum Novae Hispaniae Thesaurus" [20]. Hernandes, as translated from Latin:

"The T. corymbosa plant heals the syphilis, after exposure to cold or distortion and fracture of a bone the plant-when mixed with some resin-alleviates the pain by increasing body strength, drives out flatulence and controls an unnatural surge.

Crushed seeds help to cure diseases of the eyes when extracts mixed with milk and Chili are applied to head and forehead, stimulate sexual interaction after ingestion, crushed seeds smell strong and are mildly warm. During divination when Indians contact their gods and ask for answers they ingest plant material, go mad, develop visions and view daemons.

When suffering from gout pulverized seeds suspended in oil from Abies spec. or in white honey or Styrax liquidus (from Liquidambar 
- Table 1 Alkaloid profiles of hallucinogenic Morning Glory plants A. nervosa $[10,24]$, I. violacea $[9,10], T$. corymbosa $[9,10,35,36$, $44]$, and I. asarifolia $[10,35,36,44]$. Isoforms of the alkaloids are not listed.

\begin{tabular}{|c|c|c|c|c|}
\hline \multirow[t]{2}{*}{ Alkaloid } & \multicolumn{4}{|l|}{ Host plant } \\
\hline & A. nervosa & I. violacea & $\begin{array}{l}\text { T. corym- } \\
\text { bosa }\end{array}$ & $\begin{array}{l}\text { I. asari- } \\
\text { folia }\end{array}$ \\
\hline Chanoclavine & + & + & + & + \\
\hline Lysergic acid & & & + & \\
\hline Lysergol & & & + & \\
\hline Elymoclavine & + & + & + & \\
\hline Agroclavine & & & + & \\
\hline $\begin{array}{l}\text { Lysergic acid } \\
\text { amide (Ergine) }\end{array}$ & + & + & + & + \\
\hline $\begin{array}{l}\text { Lysergic acid } \\
\alpha \text {-hydroxy- } \\
\text { ethylamide }\end{array}$ & & & + & + \\
\hline $\begin{array}{l}\text { Ergonovine } \\
\text { (Ergometrine) }\end{array}$ & + & + & + & + \\
\hline Penniclavine & + & & & \\
\hline Setoclavine & + & & & \\
\hline Festuclavine & + & & & \\
\hline Ergobalansine & & & & + \\
\hline
\end{tabular}

orientalis Mill.) are applied to an aching body part. This will result in an astounding effect."

The seeds of the $T$. corymbosa plant are named "Oliliuhqui", meaning "the round thing" in the Nahuatl language. The plant is said to be "warm" or "mildly warm", which may refer to the fact that mammals [15] and man [21] develop hyperthermia in response to ergotism. The indigenous Indians perceive the drug as hallucinogenic and anxiolytic or as an aphrodisiac and apparently also as a remedy that alleviates pain. Serotonergic neurons are targets of ergot alkaloids and play a role in pain suppression, regulation of body temperature, and sleep control [21].

Zapotecs, Chinantecs, Mazatecs, and Mixtecs use two plant species, $T$. corymbosa and $I$. violacea $\mathrm{L}$. in religious ceremonies or healing procedures often in the presence of a shaman $[8,22]$. The seeds of $I$. violacea are called "badoh negro" by the indigenous population and are six times more potent than the brown seeds of $T$. corymbosa [9]. Approximately 13 black seeds of $I$. violacea are crushed and the active principle extracted with a liquid (alcohol or milk) and drunk. Intoxication rapidly begins and leads to visual hallucinations. The visions are often grotesque. The natives say the intoxication lasts $3 \mathrm{~h}$ and seldom has unpleasant aftereffects. The hallucinogens bring conflicts to the surface and make them more intense so that a person is more open to therapy. This is the opposite of what tranquillizers are doing which suppress the patient's problems [22].

A. nervosa, another convolvulaceous plant, was also enjoyed for its hallucinogenic ergot alkaloids. Extracts from this plant species also provide a high and, however, a miserable hangover characterized by nausea, constipation, vertigo, blurred vision, physical iner- tia [22, 23], and apparently unmotivated laughing [24], indicating that the response of human physiology to different mixtures of ergot alkaloids ( $\triangleright$ Table 1 ) can be very diverse (vide supra).

\section{The Source of Ergot Alkaloids in Mexican Morning Glories}

\section{The Morning Glory host plants (Convolvulaceae)}

Morning glory plants are characterized by beautiful funnel shaped-ephemeral flowers ( $\vee$ Fig. $\mathbf{2 A}-\mathbf{C}$ ) that often bloom in the early morning but may wilt in the afternoon of the same day. The Convolvulaceae family belongs to the order Solanales and is a sister to Solanaceae. Both families are characterized by different types of alkaloids [10]. It was Albert Hofmann [9,25] who first realized that the hallucinogenic compounds present in the Morning Glory plants are ergot alkaloids. Thus, hallucinogenic ergot alkaloids are not only produced in symbiotic systems consisting of a clavicipitaceous fungus and a grass (Poaceae) but are also present in plants characterized as vines or winding plants, members of the family Convolvulaceae. I. violacea, I. asarifolia (white and red blooming) and T. corymbosa ( $\mathbf{F i g} .2 \mathrm{~A}-\mathrm{C}$ ) contain a mixture of ergot alkaloids ( $\triangleright$ Table 1 ) including simple lysergic acid amides structurally related to LSD ( $\bullet$ Fig. 1 ) and responsible for the hallucinogenic effect [8-10].

The tribe Ipomoeeae within the family Convolvulaceae comprises an estimated 650-900 species, but only 450 species may live in a symbiotic lifestyle with ergot alkaloid-producing Periglandula fungi $[10,26]$, which are vertically transmitted by seeds between plant generations [26,27]. The plant/fungus association is likely to be the ancestral condition within the tribe Ipomoeeae. During evolution, Periglandula fungi and hence ergot alkaloid biosynthesis has been lost in four lineages within the Ipomoeeae tribe [28].

Treatment of $I$. asarifolia and $T$. corymbosa with fungicides removed Periglandula sp. from both plant species completely, resulting in a concomitant loss of alkaloids from the plants [29]. The alkaloid-free plants lend themselves to grafting experiments. In untreated plants, alkaloids reside in the aerial parts of the I. asarifolia and the $T$. corymbosa plants while the root systems are devoid of alkaloids. Grafting an alkaloid-free shoot onto a root system showed that the aerial part of the plants remained alkaloid-free. Thus, the possibility that an alkaloid-synthesizing root system shifted alkaloids into the shoot, as is known from nicotine-producing plants, is unlikely [30,31]. It follows that in I. asarifolia and $T$. corymbose, the root system is neither the site of alkaloid deposition nor of alkaloid synthesis. Investigation of Periglandula sp. and ergot alkaloids in additional species within the Convolvulaceae showed, however, that allocation of ergot alkaloids varies among species and tissues. It was concluded that this variation may reflect an ecologically determined response to selection for defense against natural enemies [32].

\section{The genus Periglandula}

Highly specialized natural products like ergot alkaloids were not expected to occur in such diverse organisms like fungi (Clavicipi- 

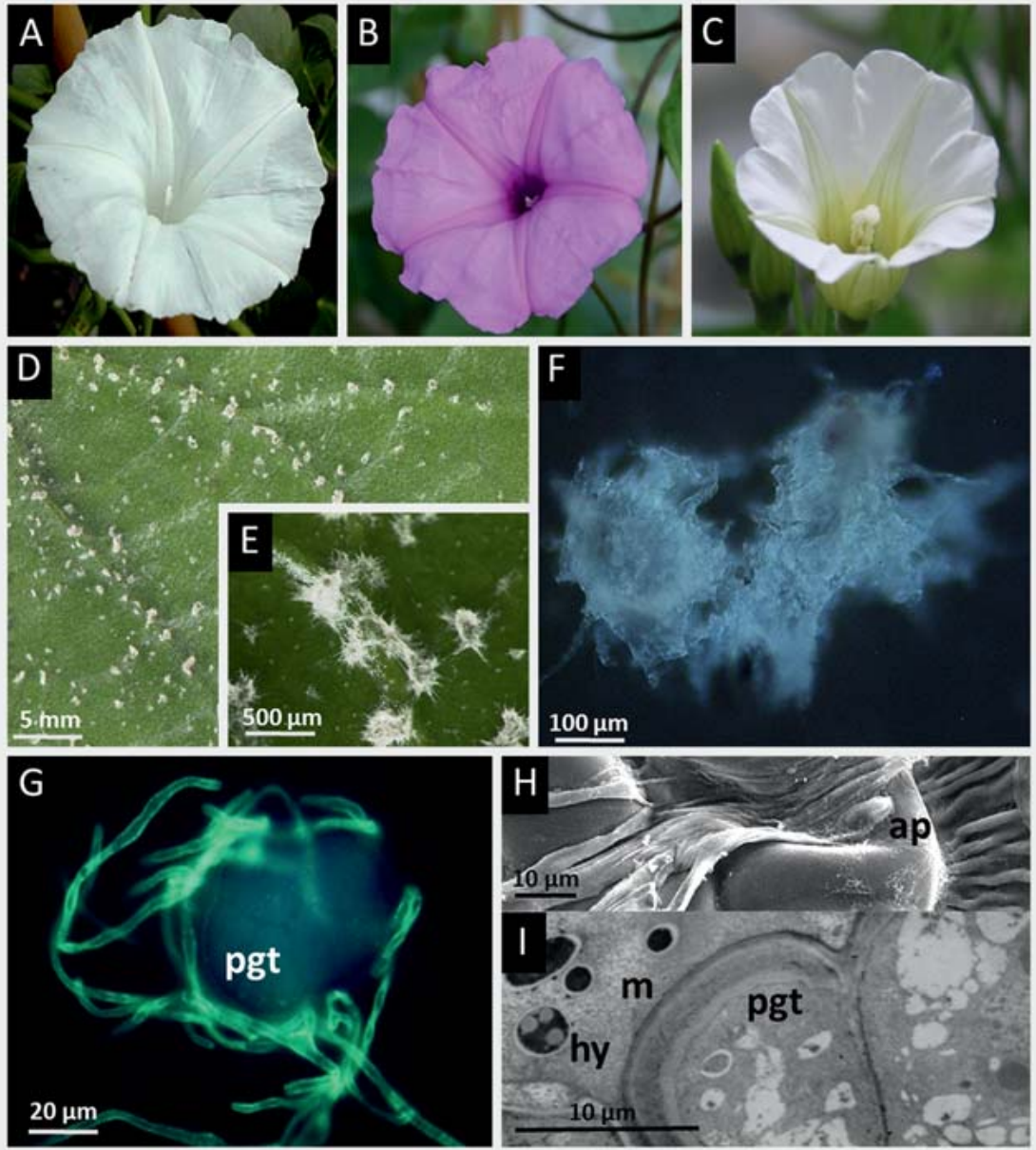

- Fig. 2 The fungus/plant symbioses Periglandula/Ipomoea or Periglandula/Turbina: flowers of the host plant I. asarifolia (A), I. asarifolia (red blooming) (B), T. corymbosa (C); epiphytic colonization of a young leaf of $T$. corymbosa by $P$. turbinae forming typical mycelium mats along the veins $(\mathrm{D}, \mathrm{E})$; ergoline alkaloids visualized by their UV-auto fluorescence within the mycelium of a young colony of $P$. ipomoeae $(\mathrm{F})$; a peltate glandular trichome (pgt) encircled by hyphae of $P$. ipomoeae forming the interface of the symbiotum (G); formation of an appressorium-like structure (ap) on the cuticle of the secretory cell of the glandular trichome indicating the close contact of fungus and plant in the symbiosis (H); hyphae (hy) of $P$. ipomoeae embedded in the matrix $(\mathrm{m})$ of subcuticular space of the peltate glandular trichome (pgt) (I).

taceae) and higher plants (Convolvulaceae). Two hypotheses were put forward to explain the erratic occurrence of ergot alkaloids in nature. The first posits that the biosynthetic pathways leading to ergot alkaloids were repeatedly invented by nature whereas the second one envisaged a horizontal gene transfer that might have occurred during evolution [3]. The assumption that an endo- or epiphytic ergot alkaloid-producing microorganism might be present in Morning Glory plants was considered but a fungus was not detected [33].

However, isolation of endophytic fungi from an ergot alkaloidcontaining plant, I. asarifolia, yielded several endophytic and one epibiotic fungus. The epibiotic fungus shows a white mycelium, which is visible by the naked eye when young leaf buds of both ergot alkaloid-containing host plants T. corymbosa [26] and I. asarifolia [27] are opened ( $\triangleright$ Fig. 2D,E). The fungus extends hyphae around the peltate glandular trichomes present on the adaxial leaf surface [29] ( $\bullet$ Fig. 2G). Hyphal structures often connect glandu- lar trichomes but never seem to penetrate the plant epidermis. Because of the unusual fungus/trichome associations, the newly described fungal genus was named Periglandula [34]. The fungus is not yet cultivable in vitro, but it was possible to isolate the mycelial mats after ultrasonic treatment of the leaves. This technique gave access to further characterization of the fungi growing on I. asarifolia (white and red blooming varieties) and T. corymbosa. Phylogenetic trees constructed from the 18SrDNA and the internal transcribed spacer grouped the fungi from both plant species into the Hypochreales, which is home to the family Clavicipitaceae (18SrDNA), and into the Clavicipitaceae proper [35, 36]. Phylogenetic trees from the beta-tubulin (tubB), RNA polymerase II large subunit (rpbA), and mitochondrial ATP synthase subunit 6 (Atp6) gave Periglandula clades sister to Claviceps and Epichloe or Balansia and Epichloe, all of which are genera within the family Clavicipitaceae. The epibiotic fungi were named Periglandula ipomoeae U. Steiner, E. Leistner et Schardl (lasaFA13 or lasacredF01 depending 
on the white and red blooming host viariety, respectively) and Periglandula turbinae U. Steiner, E. Leistner et Schardl (TcorF01). A comparison of six genes from the Periglandula species collected from the white and the red blooming I. asarifolia plants revealed no significant sequence differences [34].

In a recent attempt to extend the knowledge to symbiotic systems from different climates and different continents, eight new Periglandula species symbiotic with Convolvulaceae host plants were reported. The occurrence of ergot alkaloids coincides in every case with the presence of a Periglandula species. In the phylogeny generated from the translation elongation factor-1alpha each fungus formed a monophyletic group with $P$. ipomoeae and P. turbinae with a node confidence of $91 \%$ [34, 37]. Analyses of ergot alkaloids grouped the newly discovered symbiotic systems into four different chemotypes [37]. Further study revealed in P. ipomoeae (lasaF13) the presence of a gene cluster containing 14 ergot alkaloid genes [38-40] essential for the biosynthesis of ergopeptines and ergot alkaloids of the simple lysergic acid amide type, which are known to exert a hallucinogenic effect ( $\bullet$ Fig. 1). These data leave little doubt about the source and fungal nature of ergot alkaloids in Convolvulaceae.

\section{The Periglandula/Turbina and the Periglandula/Ipomoea symbioses}

Different species of fungi (Alternaria triticina, Glomerella cingulata, Sclerotinia sclerotiorum, Penicillium adametzoides, Penicillium olsonii, Penicillium roquefortii) isolated from an I. asarifolia plant were reinoculated onto the host plant $I$. asarifolia devoid of endophytes (after fungicide treatment). None of these fungal species, including $P$. ipomoeae, however, was reestablished and grew on the leaf surface nor was the presence of ergot alkaloids observed in the symbiotum after the inoculation process. An inoculation experiment with two ergot alkaloid-producing clavicipitaceous fungi Balansia obtecta and C. purpurea normally not associated with I. asarifolia or $T$. corymbosa and showing a relaxed host specificity triggered a necrotic response [41].

We found two ways to reestablish the epibiotic $P$. ipomoeae fungus on the I. asarifolia plant experimentally. A plantlet regenerated from a tissue culture of $I$. asarifolia was equipped with ergot alkaloids and associated solely with the $P$. ipomoeae fungus [41]. Interestingly, the cell culture is free from alkaloids [42] but contains fungal cells of $P$. ipomoeae, which were not eliminated during establishment of the plant cell culture. A surface sterilized seed of I. asarifolia germinated under axenic condition also gave rise to a plantlet containing alkaloids and associated with $P$. ipomoeae alone. These experiments demonstrate that the fungus is the alkaloid-producing organism and that the morphological differentiation of the host plant is essential for the biosynthesis of ergoline alkaloids. During morphological regeneration, the plant and $P$. ipomoeae integrate their respective partner into their own developmental program [41]. The following observation may also be of interest. One of the fungi isolated from I. asarifolia is Penicillium roquefortii, a ubiquitous and widespread fungal species. This fungus belongs to the family Trichocomaceae [43] and is a producer of ergot alkaloids such as isofumigaclavine A. As expected, the $I$. asarifolia host plant is easily inoculated by $P$. roquefortii without any necrotic or hypersensitive response; however, the symbi- otic system is completely devoid of ergot alkaloids. Microscopic inspection of the leaf surface shows that the fungus produced hyphae and conidiophores on the leaf surface, but as opposed to the $P$. ipomoeae, the hyphae of $P$. roquefortii are not attached to the glandular trichomes. This attachment may play a decisive role in the accumulation of ergot alkaloids in the Periglandula/Ipomoea or the Periglandula/Turbina symbiosis $[26,27,41]$. The cooperation between the epibiotic fungus and the host plant raises two questions: (i) which of the two associated organisms synthesizes the ergot alkaloids, fungus, or plant, and (ii) where do the alkaloids accumulate?

The presence of the complete ergot alkaloid gene cluster within the mycelium of the $P$. ipomoeae fungus strongly supports the notion that the biosynthesis proceeds within the hyphae [3840]. A reverse genetics experiment shows that the cDNA encoding the 4 - $(\gamma, \gamma$-dimethylallyl)tryptophan synthase gene is formed in vitro from the respective mRNA fraction extracted from the fungus. The chromosomal gene has the expected exon/intron structure. The encoded enzyme catalyzes the pivotal step in ergot alkaloid biosynthesis [38]. Overexpression of the gene leads to an enzyme that exhibits kinetic data in agreement with the function of a 4 - $(\gamma, \gamma$-dimethylallyl)tryptophan synthase. Detection of the enzyme by a polyclonal antibody in the hyphae but not in the leaf demonstrates that not only transcription but also translation are processes that are allocated to the clavicipitaceous Periglandula fungus [44].

Indeed, the mycelium of young leaf buds shows the typical fluorescence of the ergot alkaloids when manually opened buds are inspected under UV light ( $\bullet$ Fig. 2 F). During unfolding of the plant buds and subsequent leaf expansion, the fluorescence fades away [44]. A very minor amount of agroclavine, an early intermediate in ergot alkaloid biosynthesis, was detectable by HPLC/ MS in the fungus [27].

Periglandula sp. extends hyphae around the peltate glandular trichomes present on the adaxial leaf surface [29] ( $\bullet$ Fig. 2G). The fungal hyphae form appressorium-like structures on the cuticle and extend underneath the cuticle, forming a close contact with the cell walls of the glandular trichomes [44] ( $\triangleright$ Fig. $2 \mathbf{H}, \mathbf{I}$ ). Transport of alkaloids occurs from fungal hyphae into the plant cells until $95 \%$ of all alkaloids synthesized in the fungal hyphae are detectable in the leaves [38]. Finally, the alkaloids spread in the aerial parts of the plant and reach their highest concentration in the seeds, an observation very well known to the Mexican Indians, for they use seeds in their ritual practices.

\section{The Role of Ergot Alkaloids in Nature and in Health Care}

Ergot alkaloids represent a group of natural products that has been extensively studied for its ecology [7,16-18], biosynthesis $[3,5,39,45,46]$, molecular biology $[36,39,40]$, and impact on animal as well as human physiology $[8,10,21,47]$. This insight helps to understand why ergot alkaloids and naturally occurring compounds in general are prime candidates for the development of medications. Ergot alkaloids exert an important influence on the physiological and environmental condition of a plant $[18,26,27$, 

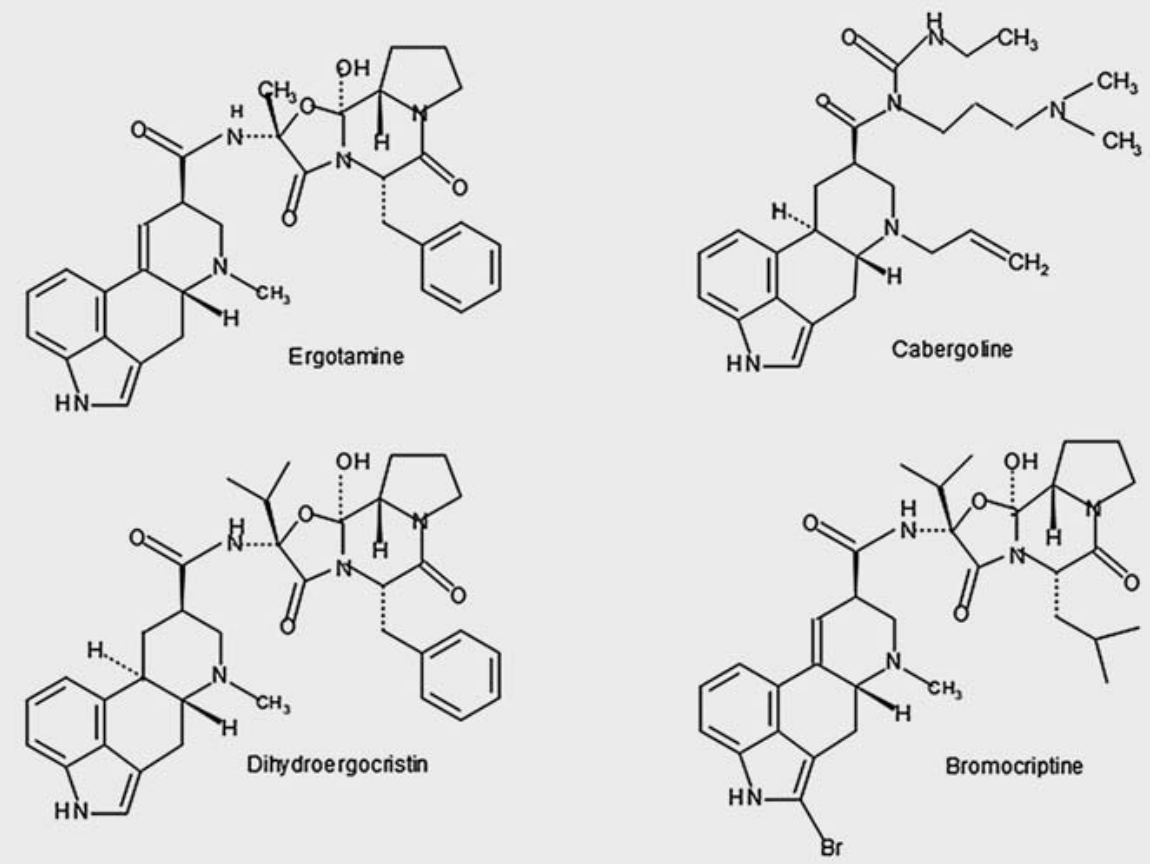

- Fig. 3 Naturally occurring ergotamine and semisynthetic natural products (cabergoline, dihydroergocristin, bromocriptin) based on the ergoline ring system. The medications are listed in the "Lauer Taxe" [56] and the "Rote Liste" [57]. Ergotamine is an antimigraine, cabergoline and bromocriptin are prolactin inhibitors, the latter also an antiparkinsonian, and dihydroergocristin (i.e., dihydroergotoxin) a remedy against impaired mental function in the elderly. Isoforms of the alkaloids are not depicted.

40]. A plant usually acquires the capacity not only for the synthesis of single but for a whole array of natural products of a certain type $[48,49]$. Plants may command synthetic capacities by themselves or employ a natural product-synthesizing endo- or epiphytic microorganism producing natural products [50]. The latter condition is observed in Convolvulaceae (e.g., T. corymbosa, I. asarifolia) living in a symbiosis with clavicipitaceous fungi (e.g., P. turbinae, $P$. ipomoea) that produce ergot alkaloids $[26,27]$. When compared to different clavicipitaceous symbiotic systems, the ergot alkaloid gene cluster in $P$. ipomoeae is likely to represent a basic and preserved structure $[39,40]$. However, the plant associated and ergot alkaloid-producing fungi do not only belong to the genus Periglandula but also to the genera Claviceps and Epichloe $[39,40]$. In general, symbiotic Clavicipitaceae are extraordinarily diverse in their host interactions [39] and their alkaloid profiles [32, 35, 39] ( Table 1). In evolutionary terms, the symbiotic systems are under selection for diversification, leading to newly developed alkaloids and alkaloid profiles assisting plants to cope with their environmental and physiological challenges $[39,40]$. The molecular biological mechanisms acting on the respective gene clusters are gene recruitments or losses, neofunctionalizations of genes, rearrangement of ergot alkaloid gene clusters, or alteration of enzyme substrate specificities resulting in new alkaloids and new alkaloid profiles (compare $>$ Table 1 ) $[39,40]$.

Natural products (e.g., alkaloids or any other natural product) optimized in this way often target neuroreceptors that exert an impact on a predator but also on the physiology of man [21]. Pre- formed physiologically active natural products are often the modeling material of a pharmacist or chemist [51] in an attempt to develop new medications. The evolutionary history and physiologically optimized structure of a natural product may constitute an advantage of the natural product over a merely synthetic chemically designed structure when new medications are developed [21]. A similar reasoning has been put forward by Bérdy [52] investigating the role of natural products in the development of medically employed antibiotics.

The peptide ergot alkaloid ergotamine ( $\triangleright$ Fig. 3 ) exhibits a strong uterotonic activity. It is a vasoconstrictor, which is mainly used against migraine. Ergotamine is the only naturally occurring ergot alkaloid that is still in use as a medication in Germany. In an attempt to obtain medications with fewer side effects and more specific pharmacological activities, ergot alkaloids were developed into semisynthetic compounds carrying the ergoline core (compare - Fig. 3). They are used in obstetrics, against female infertility, Parkinson's disease, or for the cognitive improvement of the elderly. 9,10-Dihydroergocristin is a mild hypertensive agent for the elderly, stimulating their intellectual capabilities, while bromocryptine and cabergoline are prolactin inhibitors that enable couples to fulfil their desire to have children [53,54]. Bromocryptine can also be used in addition to levodopa in the treatment of Parkinson's disease [53-57] ( Fig. 3).

Another semisynthetic alkaloid with an ergoline core is LSD ( $\triangleright$ Fig. 1), a "recreational drug" [47] discovered by Hofmann in a self-experiment after intake of $0.25 \mathrm{mg}$ [33]. This is the 5- to 10- 
fold amount of the effective dose. The molecule acts specifically on the central nervous system with a hallucinogenic, anxiolytic, and antidepressant activity. The conformation of the diethylamide moiety is key to LSD's potency. When interacting with its human serotonin $\left(5-\mathrm{HT}_{2 \mathrm{~B}} \mathrm{R}\right)$ receptor, the $\mathrm{LSD}$ molecule is covered by a peptide loop, resulting in a long residence time and a slow release of LSD from the receptor site [47]. LSD was used by physicians in attempts to restructure a patient's personality by a psychedelic therapy, unexpectedly, however, resulting in death in some cases. Attempts to employ LSD in health care were eventually discontinued in Switzerland and Germany [58]. The discussion on a possible therapeutic use of LSD, however, continues $[5,59$, $60]$.

\section{Conclusions}

Hallucinogenic plants and seeds of Convolvulaceae including those occurring in Central America such as I. asarifolia, I violacea, and T.corymbosa are colonized by species of a clavicipitaceous fungal genus that was named Periglandula. The fungus is the source of hallucinogenic ergot alkaloids. They are translocated from the fungus into the plant. While the ecological impact of ergot alkaloids on the symbioses are documented, the influence on the physiology of the host plants are greatly unexplored. The alkaloids in the genera Periglandula, Claviceps, and Epichloe (Clavicipitaceae) are examples for the role physiologically or ecologically optimized active secondary natural products can play in the development of medications.

\section{Acknowledgements}

Translation of the Latin text in Hernández et al. [20] by Ulf Timmermann, dr. phil., Rätvik, Sweden, is gratefully acknowledged. We thank Dr. Katrin Fiehe, Wiesmoor, Germany and Mrs. Tina Elzer, Koblenz, Germany, for valuable information on the Lauer Taxe.

\section{Conflict of Interest}

The authors declare no conflict of interest.

\section{References}

[1] Homöopatisches Arzneibuch (HAB 2008). Amtliche Ausgabe. Stuttgart: Deutscher Apotheker Verlag; 1991: 387-391

[2] Giger RKA, Engel G. Albert Hofmann's pioneering work on ergot alkaloids and its impact on the search of novel drugs at Sandoz, a predecessor company of Novartis. Chimia (Aarau) 2006; 60: 83-87

[3] Gröger D, Floss H. Biochemistry of Ergot Alkaloids - Achievements and Challenges. In: Cordell GA, ed. The Alkaloids: Chemistry and Biology, Vol. 50. New York: Academic Press; 1998; 50: 171-218

[4] Rehacek Z, Sajdl P. Ergot Alkaloids, Chemistry, biological Effects, Biotechnology. Praha: Academia; 1990

[5] Gröger D. Ergot. In: Kadis S, Ciegler A, Ajl SJ, eds. Microbial Toxins. New York: Academic Press; 1972: 321-373

[6] Schardl CL, Panaccione DG, Tudzynski P. Ergot Alkaloids - Biology and molecular Biology. In: Cordell GA, ed. The Alkaloids: Chemistry and Biology, Vol. 63. New York: Academic Press; 2006: 45-86

[7] Schardl CL. Introduction to special issue on ergot alkaloids. Toxins (Basel) 2015; 7: 4232-4237
[8] Schultes RE, Hofmann A. The Botany and Chemistry of Hallucinogens. Springfield: Charles C Thomas; 1973: 240-257

[9] Hofmann A. Die Wirkstoffe der Mexikanischen Zauberdroge „Ololiuqui“. Planta Med 1961; 9: 354-367

[10] Eich E. Solanaceae and Convolvulaceae: secondary Metabolites. Berlin, Heidelberg: Springer; 2008

[11] Scott PM. Ergot alkaloids: extent of human and animal exposure. World Mycotoxin J 2009; 2: 141-149

[12] Schmersahl P. Mutterkorn: Halluzinogen und Auslöser von Vergiftungen. Dtsch Apoth Ztg 2010; 150: 48-52

[13] Caporael LR. Ergotism: the satan loosed in Salem? Convulsive ergotism may have been a physiological basis for the Salem witchcraft crisis in 1692. Science 1976; 192: 21-26

[14] Eadie MJ. Convulsive ergotism: epidemics of the serotonin syndrome? Lancet Neurol 2003; 2: 429-434

[15] Klotz JL. Activities and effects of ergot alkaloids on livestock physiology and production. Toxins (Basel) 2015; 7: 2801-2821

[16] Schardl CL, Leuchtmann A. The Epichloe Endophytes of Grasses and the symbiotic Continuum. In: Dighton J, White JF jr., Oudemans PV, eds. The fungal Community: its Organisation and Role in the Ecosystems, Vol. 23. Boca Raton: CRC Taylor and Francis; 2005: 475-503

[17] Porter JK, Thompson FN jr. Effects of fescue toxicosis on reproduction in livestock. J Anim Sci 1992; 70: 1594-1603

[18] Dinkins RD, Nagabhyru P, Graham MA, Boykin D, Schardl CL. Transcriptome response of Lolium arundinaceum to its fungal endophyte Epichloe coenophiala. New Phytol 2016; 213: 324-337

[19] Negard M, Uhlig S, Kauserud H, Andersen T, Hoiland K, Vralstad T. Links between genetic groups, indole alkaloid profiles and ecology within the grass-parasitic Claviceps purpurea species complex. Toxins (Basel) 2015; 7: $1431-1456$

[20] Hernandez F, Recchi NA, Lynceus JT. Rerum Medicarum Novae Hispaniae Thesaurus, 3rd ed. Rome: 1651: 145-146

[21] Wink M. Interference of Alkaloids with Neuroreceptors and Ion Channels. In: Atta-Ur-Rahman, ed. Studies in Natural Products Chemistry, Vol. 11. New York: Elsevier; 2000: 3-122

[22] Schultes RE, Hofmann A. Plants of the Gods. Their sacred, healing and hallucinugenic Powers. Rochester: Healing Arts Press; 1992: 178

[23] Emboden W. Narcotic Plants. London: Studio Vista; 1972: 26

[24] Paulke A, Kremer C, Toennes SW. Argyreia nervosa: Erfahrungen mit einem pflanzlichen Legal High. Pharmakon 2013; 1: 463-469

[25] Stauffacher D, Tscherter H, Hofmann A. Isolierung von Ergosin und Ergosinin neben Agroclavin aus den Samen von Ipomoea argyrophylla VATKE (Convolvulaceae). Helv Chim Acta 1965; 6: 1379-1380

[26] Leistner E, Steiner U. Fungal Origin of ergoline Alkaloids present in dicotyledonous Plants (Convolvulaceae). In: Esser K, ed. The Mycota, Vol. 15. Berlin, Heidelberg: Springer; 2006: 197-208

[27] Steiner U, Leistner E. Ergoline alkaloids in convolvulaceous host plants originate from epibiotic clavicipitaceous fungi of the genus Periglandula. Fungal Ecol 2012; 5: 316-321

[28] Eserman LA, Tiley GP, Jarret RL, Leebens-Mack JH, Miller RE. Phylogenetics and diversification of Morning Glories (Tribe Ipomoeeae, Convolvulaceae) based on whole plastome sequences. Am J Bot 2014; 101: 112

[29] Kucht S, Groß], Hussein Y, Grothe T, Keller U, Basar S, König WA, Steiner $\mathrm{U}$, Leistner E. Elimination of ergoline alkaloids following treatment of Ipomoea asarifolia (Convolvulaceae) with fungicides. Planta 2004; 219: 619-625

[30] Mothes K, Schütte HR, Luckner M. Biochemistry of Alkaloids. Berlin: VEB Deutscher Verlag der Wissenschaften; 1985: 54

[31] Hellwig S. Ergolinvorkommen bei Convolvulaceen. Biochemische und ökologische Interaktionen einer Pflanze-Pilz-Symbiose [Dissertation]. Bonn: Rheinische Friedrich-Wilhelms-Universität; 2007 
[32] Beaulieu WT, Panaccione DG, Hazekamp CS, Mckee MC, Ryan KL, Clay K. Differential allocation of seed-borne ergot alkaloids during early ontogeny of Morning Glories (Convolvulaceae). J Chem Ecol 2013; 39: 919930

[33] Hofmann A. LSD - mein Sorgenkind, die Entdeckung einer „Wunderdroge“, 12. Aufl. München: dtv; 1993: 132

[34] Steiner U, Leibner S, Schardl CL, Leuchtmann A, Leistner E. Periglandula, a new fungal genus within the Clavicipitaceae and its association with Convolvulaceae. Mycologia 2011; 103: 1133-1145

[35] Ahimsa-Müller MA, Markert A, Hellwig S, Knoop V, Steiner U, Drewke C, Leistner E. Clavicipitaceous fungi associated with ergoline alkaloid-containing Convolvulaceae. J Nat Prod 2007; 70: 1955-1960

[36] Steiner U, Ahimsa-Müller MA, Markert A, Kucht S, Groß J, Kauf N, Kuzma M, Zych M, Lamshöft M, Furmanowa M, Knoop V, Drewke C, Leistner E. Molecular characterization of a seed transmitted clavicipitaceous fungus occurring on dicotyledonous plants (Convolvulaceae). Planta 2006; 224 : 533-544

[37] Beaulieu WT, Panaccione DG, Ryan KL, Kaonongbua W. Phylogenetic and chemotypic diversity of Periglandula species in eight new Morning Glory hosts (Convolvulaceae). Mycologia 2015; 107: 667-678

[38] Markert A, Steffan N, Ploss K, Hellwig S, Steiner U, Drewke C, Li SM, Boland W, Leistner E. Biosynthesis and accumulation of ergoline alkaloids in a mutualistic association between Ipomoea asarifolia (Convolvulaceae) and a clavicipitalean fungus. Plant Physiol 2008; 147: 296-305

[39] Schardl CL, Young CA, Hesse U, Amyotte SG, Andreeva K, Calie P], Fleetwood DJ, Haws DC, Moore N, Oeser B, Panaccione DG, Schweri KK, Voisey CR, Farman ML, Jaromczyk JW, Roe BA, O'Sullivan DM, Scott B, Tudzynski P, An Z, Arnaoudova EG, Bullock CT, Charlton ND, Chen L, Cox M, Dinkins RD, Florea S, Glenn AE, Gordon A, Güldener U, Harris DR, Hollin W, Jaromczyk J, Johnson RD, Khan AK, Leistner E, Leuchtmann A, Li C, Liu J, Liu J, Liu M, Mace W, Machado C, Nagabhyru P, Pan J, Schmid J, Sugawara K, Steiner U, Takach JE, Tanaka E, Webb JS, Wilson EV, Wiseman JL, Yoshida R, Zeng Z. Plant symbiotic fungi as chemical engineers: multi-genome analysis of the Clavicipitaceae reveals dynamics of alkaloid loci. PLoS Genet 2013; 9: e1003323

[40] Florea S, Panaccione DG, Schardl CL. Ergot alkaloids of the family Clavicipitaceae. Phytopathology 2017; 5: 504-518

[41] Steiner U, Hellwig S, Leistner R. Specificity in the interaction between an epibiotic clavicipitalean fungus and its convolvulaceous host in a fungus/ plant symbiotum. Plant Signal Behav 2008; 3: 704-706

[42] Hassan NS, Hashem E, Amine GH, Hussein Y, El-Zawahry YA, Leistner E. Biochemical detection of ergoline alkaloids in Rivea corymbosa L. (Convolvulaceae) cell suspension cultures. Egypt J Biotechnol 2004; 16: 331-349

[43] Wallway C, Li SM. Ergot alkaloids: structure diversity, biosynthetic gene clusters and functional proof of biosynthetic genes. Nat Prod Rep 2011; 28: 496-510
[44] Steiner U, Kucht S, Ahimsa-Müller MA, Grundmann N, Li SM, Drewke C, Leistner $\mathrm{E}$. The key role of peltate glandular trichomes in symbiota comprising clavicipitaceous fungi of the genus Periglandula and their host plants. Toxins (Basel) 2015; 7: 1355-1373

[45] Young CA, Schardl CL, Panaccione DG, Florea S, Takach JE, Charlton ND, Moore N, Webb JS, Jaromczyk J. Genetics, genomics and evolution of ergot alkaloid diversity. Toxins (Basel) 2015; 7: 1273-1302

[46] Gerhards N, Neubauer L, Tudzynski P, Li SM. Biosynthetic pathways of ergot alkaloids. Toxins (Basel) 2014; 6: 3281-3295

[47] Wacker D, Wang S, McCorvy JD, Betz RM, Venkatakrishnan AJ, Levit A, Lansu K, Schools ZL, Che T, Nichols DE, Shoichet BK, Dror RO, Roth BL. Cristal structure of an LSD-bound human serotonin receptor. Cell 2017; 168: 377-389

[48] Eisner T. For Love of Insects. Cambridge: Harvard University Press; 2003

[49] Harborne JB. Introduction to Ecological Biochemistry, 4th ed. London: Academic Press; 2004

[50] Gunatilaka AAL. Natural products from plant-associated microorganisms: distribution, bioactivity, and implications of their occurrence. J Nat Prod 2006; 69: 509-526

[51] Floss HG. Combinatorial biosynthesis-potential and problems. J Biotech 2006; 124: 242-257

[52] Bérdy ]. Bioactive microbial metabolites. A personal view. J Antibiot 2005; 58: 1-26

[53] Crosignani PG. Current treatment issues in female hyperprolactinaemia. Science Direct 2006; 125: 152-164

[54] de Groot NJA, van Dongen PW], Vree TB, Hekster YA, van Roosmalen L. Ergot alkaloids, current status and review of clinical pharmacology and therapeutic use compared with other oxytocics in obstetrics and gynaecology. Drugs 1998; 56: 523-535

[55] Burn D. Parkinson's disease: treatment. Pharm J 2000; 264: 476-479

[56] LAUER-TAXE R Datenbank. Version: WEBAPO R Info-system. Date: April 15, 2017. Keywords: ergotamine or cabergoline or dihydroergocristin or bromocriptine

[57] Rote Liste Service GmbH, ed. Arzneimittelverzeichnis für Deutschland. Frankfurt/Main: Rote Liste Service GmbH; 2016

[58] Nuhn P. Die Wunderdroge. Vor 70 Jahren wurde die Wirkung des LSD entdeckt. Dtsch Apoth Ztg 2013; 153: 70-71

[59] Winkelmann M. Psychedelics as medicines for substance abuse rehabilitation: evaluating treatments with LSD, Peyote, Ibogaine and Ayahuasca. Curr Drug Abuse Rev 2014; 7: 101-116

[60] Liester MB. A review of lysergic acid diethylamide (LSD) in the treatment of addictions: historical perspectives and future prospects. Curr Drug Abuse Rev 2014; 7: 146-156 